\title{
High-speed Planning Method for a Cooperative Logistics Network using Mixed Integer Programming Model and Dummy Load
}

\author{
Takashi Onoyama Member (Hitachi Software, onoyama@hitachisoft.jp) \\ Sen Kubota Non-member (Hitachi Software, kubosen@hitachisoft.jp) \\ Takuya Maekawa Non-member (Hitachi Software,takum@hitachisoft.jp) \\ Norihisa Komoda Senior Member (Osaka University, komoda@ist.osaka-u.ac.jp)
}

Keywords : logistics planning, cooperative logistics, mixed integer programming, optimization

Adequate response performance is required for the planning of a cooperative logistics network covering multiple enterprises, because this process needs a human expert's evaluation from many aspects. To satisfy this requirement, we propose an accurate model based on mixed integer programming for optimizing cooperative logistics networks where "round transportation" exists together with "depot transportation" including lower limit constraints of loading ratio for round transportation vehicles. Furthermore, to achieve an interactive response performance, a dummy load is introduced into the model instead of integer variables.

To improve logistics efficiency, we intend to build logistics cooperation over multiple enterprises that belong to a single supply chain. The purpose of our research is to provide an effective planning method for a cooperative logistics network comprised of many enterprises such as manufacturing plants, parts suppliers, and transportation companies.

A simple mathematical optimal plan is not usually readily accepted because of conflicts that arise in the different enterprises in the supply chain. Thus, a human expert must evaluate the plan from many aspects and coordinate it.

The minimum cost flow model is applied to optimize a large-scale distribution network. This model is premised on uniform transportation of "depot transportation." That is, all parts suppliers deliver their parts to depots, and the depots transport these parts to factories. However, another kind of transportation, "round transportation" is used in the cooperative network. A round-transportation vehicle goes around to several parts suppliers to pick up parts and then delivers them directly to a factory where they will be used. Thus, a simple mathematical model based on the minimum cost flow problem cannot precisely evaluate a cooperative network.

An integer programming-based method was proposed for the planning of a long distance transportation network. Although this method is suitable for use in a complicated network such as ours, it is not satisfactory in terms of the response performance.

To implement the planning process of the cooperative logistics network, the technical problems of interactive response performance and human expert-level optimality must be addressed.

To achieve both interactive response performance and high otimimality, a model for round transportation without integer-variables is proposed. Instead of integer variable, real variable, which indicates the shortage of load from criterion of each round transportation route, is introduced to the model.

That is, if the loading ratio of a round transportation vehicle is less than the lower limit, dummy loads are taken to the vehicle, and the transportation cost of the dummy loads is added to the objective function.

We can evaluate the cooperative logistics network including round transportation with the following process; (1) To search round transportation routes where the load does not reach criterion, we solve the above model. (2) Round transportation routes that take on dummy loads are deleted from candidate round transportation candidate routes. (3) The model is resolved by using the newly calculated set $\mathrm{T}$ to obtain the total transportation costs including round transportation costs.

To confirm the efficiency of the proposed method, the following three solution method were evaluated. 1) Depot-access approcximation method 2) Inger variable method 3) Proposed method.

Table 1 lists the number of real variables, integer variables (0-1 variables), constraints, and processing time of each solution method. The depot-access approximation method can solve the problem in less than one minutes. On the other hand, the response time of the proposed method was within three minutes, while the response time of the integer variable method exceeded one hour.

Table 2 presents the cost evaluation results of each method. The integer variable method and the proposed method obtained the same logistics structure. Their costs were based on the structure and were nearly equal to the human expert's solution. On the other hand, the depot-access approximation method calculated a cost that was at least $10 \%$ higher compared with the other solutions.

Table 1. Model size and response-time

\begin{tabular}{|c|l|c|c|c|c|}
\hline$\#$ & Method & $\begin{array}{l}\text { Real } \\
\text { var }\end{array}$ & $\begin{array}{l}\text { Int. } \\
\text { var }\end{array}$ & Constraint & $\begin{array}{l}\text { Response } \\
\text { time(min.) }\end{array}$ \\
\hline 1 & $\begin{array}{l}\text { Depot } \\
\text { approximation }\end{array}$ & 6,640 & 0 & 4,892 & 0.8 \\
\hline 2 & Integer variable & 18,640 & 200 & 9,272 & 83 \\
\hline 3 & $\begin{array}{l}\text { Proposed } \\
\text { method }\end{array}$ & 18,840 & 0 & 9,272 & 2.4 \\
\hline
\end{tabular}

Table 2. Accuracy of each method

\begin{tabular}{|c|l|c|c|}
\hline$\#$ & \multicolumn{1}{|c|}{ Method } & Cost & Error(\%) \\
\hline 1 & Depot approximation & 16,801 & 11.3 \\
\hline 2 & Integer variable & 14,784 & 0 \\
\hline 3 & Proposed method & 14,784 & 0 \\
\hline
\end{tabular}




\title{
巡回輸送を含む共同物流網の計画のための混合整数計画問題
}

\section{モデル化とダミー荷物を用いた高速解法}

\author{
正員 小野山 隆* 非会員 久保田 仙* \\ 非会員 前川 拓也* 上級会員 薦田 憲久**
}

\section{High-Speed Planning Method for Cooperative Logistics Networks using Mixed Integer Programming Model and Dummy Load}

Takashi Onoyama*, Member, Sen Kubota*, Non-member, Takuya Maekawa*, Non-member,

Norihisa Komoda**, Senior Member

Adequate response performance is required for the planning of a cooperative logistic network covering multiple enterprises, because this process needs a human expert's evaluation from many aspects. To satisfy this requirement, we propose an accurate model based on mixed integer programming for optimizing cooperative logistics networks where "round transportation" exists together with "depot transportation" including lower limit constraints of loading ratio for round transportation vehicles. Furthermore, to achieve interactive response performance, a dummy load is introduced into the model instead of integer variables. The experimental result shows the proposed method obtains an accurate solution within interactive response time.

キーワード：物流計画，共同物流，混合整数計画，最適化

Keywords : logistics planning, cooperative logistics , mixed integer programming, optimization

\section{1. はじめに}

物流の効率化は経済面だけでなく, $\mathrm{CO}_{2}$ 削減など環境面 や社会面からも重要な課題であるが，多品種少量生産の増 大や調達範囲の拡大のため, 低積載率輸送や長距離輸送が 増大しているのが実情である(1)。この問題の解決には，サプ ライチェーンを構成する企業の物流の共同化が有力な手段 である。本研究は, メーカーと, その部品サプライヤによ る共同物流網の効率的な計画作成手法の実現を目指してい る。従来の部品サプライヤ単位での物流最適化から, より 広範な調達物流網全体での最適化を実現するために, 効果 的な物流計画の作成手法が求められている。

この部品調達共同物流網は, 部品サプライヤからデポ (物 流センタ）への輸送を行う集荷網や，デポと工場間等の輸 送を行う幹線物流網, 複数の部品サプライヤを巡回して直

\footnotetext{
* 日立ソフトウェアェンジニアリング (株)

干140-0002 東京都品川区東品川 4-12-7

Hitachi Software Engineering Co.,Ltd.

4-12-7 Higashishinagawa, Shinagawa, Tokyo 140-0002

** 大阪大学大学院 情報科学研究科

干556-0871 大阪府吹田市山田丘 2-1

Graduate School of Information Science and Technology, Osaka University

2-1, Yamadaoka, Suita, Osaka 556-0871
}

接工場への輸送を行う巡回輸送網など，互いに関連する多 くのサブネットワークから構成されている。この様な物流 計画の作成には，デポや車両，要員等のリソースの準備と， そのリソースのサブネットワークへの割り当て, 更に, 各 サブネットワークの物流計画の作成までもが必要である。 この物流網構築は非常に複雑な問題であり, 通常, いくつ かのフェーズに分割して段階的に構築を行う(2)(3)。

著者らは, この共同物流網の構築を,「構築フェーズ」と 「スケジューリングフェーズ」の二つのフェーズで行う方式 を提案している(4)。戦略や戦術レベルの計画作成に該当する 構築フェーズでは, 生産計画に対応した調達計画の作成や, 車両や人員などのリソースのサブネットワークへの割当を 行う。次のスケジューリングフェーズでは, 運用レベルの 物流スケジュールまで作成して, 運用性や, 使用車両台数 に基づく, より詳細なコストの評価を行う。また, 共同物 流は参加企業（メーカー，部品サプライヤ，輸送業者, 倉 庫業者等）の利害が絡むため，単に数理的な最適解が，そ のまま受け入れられることは殆どない。担当者はシステム 化されていない条件まで考慮して, 多面的な評価・調整を 行う必要がある。

このスケジューリングフェーズは, 複数台の車両による 
デポと部品サプライヤ間の輸送計画作成を行う配送計画問 題(VRP: Vehicle Routing Problem)に該当する ${ }^{(2)}$ 。この配送 計画問題には，スィープ法やセービング法など，比較的単 純な解法や, Cross-opt 近傍などの局所探索(5)を, タブーサ 一チや SA 法などのメタヒューリスティクスに適用した解 法(6)も提案されている。著者らも，これらのヒューリスティ クスを用いた配送計画問題の解法を構築し，スケジューリ ングフェーズに要求される対話的な応答性能と専門家レベ ルの精度の両立が実現できることを確認している(7)。本論文 では，更に，「構築フェーズ」でも対話的な応答性を実現す る解法を提案する。

従来，物流網の戦略や戦術レベルの構築には，最小費用 流問題をベースとしたモデルが用いられている。これらの モデルは，全ての輸送が一様にデポを経由して行われるこ とを前提としている。このため，ここで対象としている， デポ経由の集荷と巡回輸送が混在する物流網を正確に評価 することができない。

幹線輸送網の物流計画作成手法として，整数計画を用い たモデルも提案されている。この方式は構造が複雑な物流 網にも適用できるが, 応答性能の面で利用が困難である(8)。

また，巡回輸送で輸送可能な荷物を予め巡回輸送に割当 て，その残りの荷量をデポ経由での輸送に割り当てる方式 も提案されている(9)。この手法は全体の荷量が物流網の輸送 能力に比べて充分に多い場合には，ある程度正確な評価が 行えるが，荷量が少ない場合には誤差が大きくなってしま うという問題点がある。

物流網を複数のデポを有する配送計画問題として捉え， タブーサーチを適用する手法も提案されている(10)。しかし， 大規模な物流網の構築では，対話的な応答時間を実現する ことが困難である。

本論文では，対話的な応答性能と精度の両立を図る共同 物流網のモデル化と，その解法を提案する。本手法により， 共同物流網の対話的な構築を実現できる。

2 章では, 共同物流網の特徵と, その構築上の技術的課題 を説明する。 3 章で共同物流網構築問題のモデルを提示し, 4 章で高速高精度な解法を提案する。 5 章で評価実験の結果 を示し， 6 章で結論を述べる。

\section{2. 共同物流網の構築}

〈2·1〉 物流共同化の特徵 メーカーは, 部品をサプ ライヤから調達して製品を生産しているが，市場競争に勝 つために，この部品の調達物流コストの削減が強く求めら れている。従来は, 部品サプライヤが個別にメーカーの工 場に部品を納入していた。しかし, 多品種少量生産の増大 や調達エリアの拡大に伴い，物流コストが増大している。 このため調達物流網全体での最適化を目指して, 部品サプ ライヤとメーカーが一体となった物流の共同化を行ってい る。

ここで対象とする共同物流網では，輸送する部品サイズ や，製品のライフサイクルが数カ月程度と短いために，大
規模なデポを固定的に設けてはいない。製品ライフサイク ルに合わせて柔軟に物流網を調節するため, 中小規模のデ ポの開設，閉鎖を行って運用している。また，部品サプラ イヤから工場への部品の輸送も, 全てデポを経由して輸送 するのではなく, いくつかの部品サプライヤを巡回して直 接輸送する巡回輸送も行われている。この巡回輸送で扱わ れる荷量は全輸送量の $30 \%$ 程度にも達している。

〈2·2〉物流網の構造物流網は図 1 に示すように部 品サプライヤと工場, デポをノードとするネットワークで ある。工場へはデポまたは部品サプライヤから部品を納入 する。また, デポには部品サプライヤから部品を納入し, 工場もしくは他のデポに部品を出荷する。

ノード間の輸送は次の 2 種類のルートで行われる。

1）デポ経由輸送ルート：複数の部品サプライヤを巡 回してデポに部品を集荷し, 幹線輸送用の大型車両で工場 に輸送するルート

2）巡回輸送ルート： 複数の部品サプライヤを巡回し て部品を集荷し，デポを経由せずに直接工場に輸送するル 一ト

一般的に，巡回輸送による輸送はデポへの集荷に利用す る車両よりも大型の車両を利用する。更に, 巡回輸送では デポも利用しないため, 荷物個別の輸送コストはデポを経 由した場合よりも低くなる。

巡回輸送ルートは, 部品の供給能力が一定以上の部品サ プライヤの中で, その出荷時間枠と, 車両の走行距離の制 約を元に, 1 台の車両で巡回可能な部品サプライヤの組合せ を求めて設定される。部品サプライヤからの部品輸送を, デポ経由ではなく，この巡回輸送で行う条件は以下の通り である。

（1）部品サプライヤから工場への輸送量が基準量以上 あること。

（2）巡回輸送する車両の積載量が一定以上確保できる こと。

たとえ，一つの部品サプライヤから，工場への出荷量が， 基準量を超えていても, 他の部品サプライヤの出荷量が少 なく, 車両の基準積載量に達しない場合には巡回輸送は行 わずデポ経由での輸送を行う。

$\langle 2 \cdot 3\rangle$ 物流網の構築手法と技術的課題 共同物流網

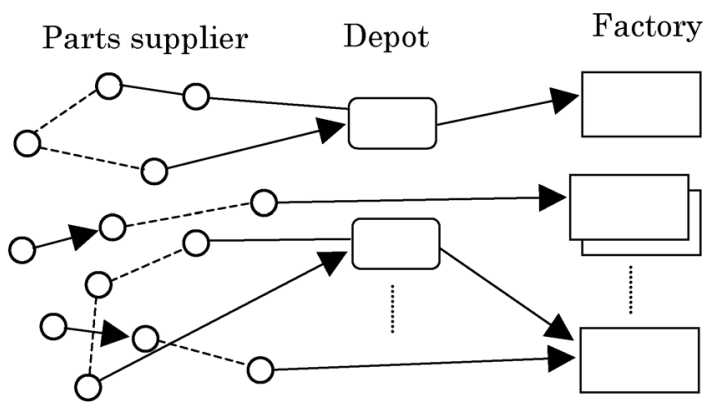

図 1 共同物流網の構造

Fig. 1. Structure of the cooperative logistics network. 


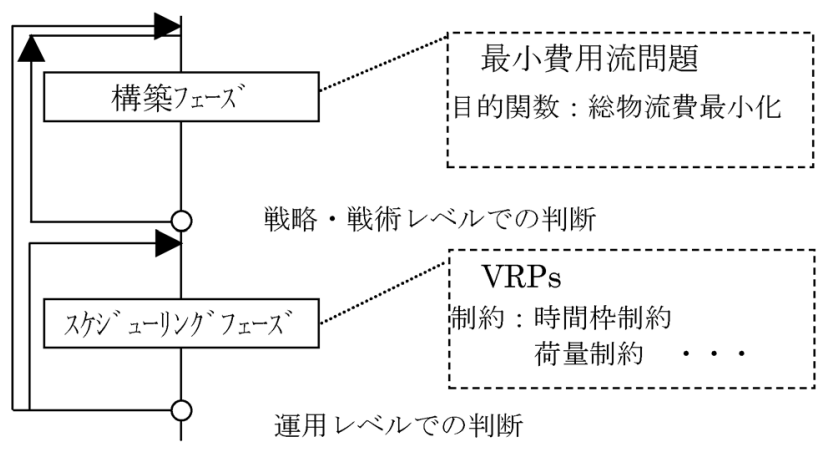

図 2 共同物流網の構築手順

Fig. 2. Planning process for the cooperative logistics network.

の構築は，物流効率向上の有力な手段である。しかし物流 の共同化には各企業の利害が絡むため, 単に数理的な最適 解がそのまま受け入れられることは殆ど無い。デポごとの 負荷の公平化や庸車コスト削減のための発注先輸送会社の 集中化, 部品サプライヤの納入条件の調整など, 担当者は システムに組み入れられていない様々な条件を考慮するた めに多面的な評価・調整を行う必要がある。このためには, 図 2 に示寸ように，デポの開設閉鎖や集荷能力，また幹線 輸送力などの物流網の構築フェーズの計画作成と共に, 運 用性の評価やより正確な物流コストを把握するために，ス ケジューリングフェーズでの各輸送ルートの物流計画の作 成までのプロセスを繰り返し行う必要がある。

図 2 のプロセスによる共同物流網構築を実現するために は, 以下の技術的課題の解決が必要である。

（1）対話的な応答性能の確保 人間の専門家が多面 的な評価・調整を行うためには，少なくとも 1 時間に 2 回 程度の対話的処理が可能な性能が要求される。複雑な物流 網の構築に整数計画法を用いる手法も提案されているが, 対話的な応答性能の実現が困難である。このため, 整数変 数を用いない共同物流網のモデル化が必要である。

（2）専門家レベルの精度の確保 戦略・戦術レベルの 計画を作成する構築フェーズには，少なくとも人間の専門 家と同レベルの高い最適性が求められる。従来, 大規模な 物流網全体の構築には, 最小費用流問題によるモデル化が 用いられている。このモデルでは巡回輸送を意識せずに部 品サプライヤから工場への輸送は全てデポを経由した輸送 として計算するものである。全輸送量に占める巡回輸送の 割合が小さければ，全てデボ経由の輸送として扱っても大 きな誤差は出ない。しかし, 本研究の対象としている共同 物流網では, 巡回輸送が全体の $30 \%$ 程度を占めているため, 大きな誤差の要因となる。

また，これとは逆に巡回輸送で輸送可能な荷物は，全て 巡回輸送を用い, 残荷量だけデポ経由に割り当てるアプロ 一チも提案されている(9)。しかし，この手法では巡回輸送を 行える部品サプライヤからの調達を, 他のサプライヤから の調達よりも無条件に優先するなどの問題が生じてしま
う。専門家レベルの精度を確保するためには, 巡回輸送も デポ経由の輸送も区別しないモデル化が必要である。

\section{3. 共同物流網構築問題のモデル化}

〈3・1〉最小費用流によるモデル化図 1 にデボ経由 輸送と巡回輸送が混在した共同物流網の最小費用流による モデルを示す。

以下の記法を用いる。

$\mathrm{G}=(\mathrm{N}, \mathrm{A})$ ：ノードの集合 $\mathrm{N}$ とアーク集合 $\mathrm{A}$ から構成され るネットワーク

$\mathrm{s}:$ 部品サプライヤの集合

C: デポの集合

$\mathrm{F}$ ：工場の集合

$\mathrm{N}=\mathrm{S} \cup \mathrm{C} \cup \mathrm{F}, \mathrm{S} \cap \mathrm{C} \cap \mathrm{F}=\Phi$

$\mathrm{D}$ ：部品サプライヤとデポを結ぶアークの集合

$\mathrm{M}$ ：デポと工場を結ぶアークの集合

$\mathrm{E}$ ：部品サプライヤと工場を結ぶアークの集合

$\mathrm{A}=\mathrm{D} \cup \mathrm{M} \cup \mathrm{E}$

$\mathrm{P}$ : 部品の集合

$v^{p}:$ 部品 $p$ の単位量あたりの荷量（容積）

$s u_{i}^{p}$ : サプライヤ $i$ の部品 $p$ の最大供給量 $(i \in \mathrm{S}, p \in \mathrm{P})$

$d m_{k}^{p}:$ 工場 $k$ での部品 $p$ の需要量 $(k \in \mathrm{F}, p \in \mathrm{P})$

$c_{i j}^{p}$ : 部品 $p$ の単位量あたりのノード $i$ から $j$ への輸送

コスト $(i, j \in \mathrm{N}, p \in \mathrm{P})$

$d_{i}^{p}:$ デポ $i$ での部品 $p$ の単位量あたりの処理コスト

$(i \in \mathrm{C}, p \in \mathrm{P})$

$c u_{i}$ : デポ $i$ の取り扱い荷量（荷物容積）上限 $(i \in \mathrm{C})$

$t_{i j}$ : デポ $i$ と工場 $j$ 間の輸送量上限 $\quad(i \in \mathrm{C}, j \in \mathrm{F})$

$x_{i j}^{p}$ : 部品 $p$ のノード $i$ から $j$ への輸送量を表す実変数

$(i, j \in \mathrm{N}, p \in \mathrm{P})$

$\mathrm{T}$ ：巡回輸送ルートの集合

$\mathrm{St}:$ 巡回輸送ルート $t$ に含まれる部品サプライヤの集合 $(t \in \mathrm{T})$

$f t$ : 巡回輸送ルート $t$ の納入先工場 $(t \in \mathrm{T}, f t \in \mathrm{F})$

$y_{i j}^{p t}$ : 巡回輸送ルート $t$ による部品 $p$ のノード $i$ から $j へ の$

輸送量を表す実変数 $(i \in \mathrm{C}, j \in \mathrm{F} t \in \mathrm{T}, p \in \mathrm{P})$

$t_{0}$ : 部品サプライヤの巡回輸送出荷基準量

$t_{1}$ : 巡回輸送車両の基準積載量

$t_{2}$ : 巡回輸送車両の最大積載量

このとき, 巡回輸送ルート $t$ による輸送コストは(1)式で 表される。

$$
C_{t}=\sum_{p \in P} \sum_{i \in S_{t}} c_{i t}^{p} \cdot y_{i t t}^{p t} \quad \forall t \in \mathrm{T} \cdot \cdots
$$

従って, 目的関数は以下の (2)式で表され, 制約条件は(3) 式から(8)式で表現される。

Objective:

$$
\begin{aligned}
& \sum_{p \in P}\left(\sum_{i \in S} \sum_{j \in C}\left(c_{i j}^{p}+d_{j}^{p}\right) \cdot x_{i j}^{p}+\sum_{j \in C} \sum_{k \in F} c_{j k}^{p} \cdot x_{j k}^{p}\right)+\sum_{t \in T} C_{t} \\
& \rightarrow \min
\end{aligned}
$$


Subject to:

$$
\begin{array}{ll}
\sum_{j \in C} x_{i j}^{p}+\sum_{t \in T} y_{i j t}^{p t} \leq s u_{i}^{p} & \forall i \in \mathrm{S}, p \in \mathrm{P} \cdots \\
\sum_{j \in C} x_{j k}^{p}+\sum_{t \in T} \sum_{i \in S_{t}} y_{i k}^{p t}=d m_{k}^{p} & \forall k \in \mathrm{F}, p \in \mathrm{P} \cdots \cdots \\
\sum_{i \in S} x_{i j}^{p}=\sum_{k \in F} x_{j k}^{p} & \forall j \in \mathrm{C}, p \in \mathrm{P} \cdot \\
\sum_{p \in P} \sum_{i \in S} v^{p} \cdot x_{i j}^{p} \leq c u_{j} & \forall j \in \mathrm{C} \cdots \cdots \cdots \\
\sum_{p \in P} v^{p} \cdot x_{j k}^{p} \leq t_{j k} & \forall j \in \mathrm{C}, k \in \mathrm{F} \cdots \\
t_{1} \leq \sum_{p \in P} \sum_{i \in S_{t}} v^{p} \cdot y_{i t}^{p t} \leq t_{2} & \forall t \in \mathrm{T} \cdots \cdots \cdots \cdots \cdots
\end{array}
$$

この最小費用流のモデルでは, 全ての巡回輸送ルートに 基準積載量 $\left(t_{1}\right)$ 以上の荷量が無ければ解が存在しなくなって しまう。また, 基準積載量の制約条件を緩和すると, 輸送 コストの低い巡回輸送が無条件に優先されてしまう。この 問題点を回避するために, 次に混合整数計画をべースとし たモデルを示す。

〈3.2〉混合整数計画によるモデル化巡回輸送を整 数変数を用いた混合整数計画問題としてモデル化する。ま ず巡回輸送ルートの積載量の条件を， $0-1$ 変数 $z_{t}(t \in \mathrm{T}) を$ 用 いて次の $(9)$ 式で表現する。

$$
t_{1} \cdot z_{t} \leq \sum_{p \in P} \sum_{i \in S t} v^{p} \cdot y_{i j t}^{p t} \leq t_{2} \cdot z_{t} \quad \forall t \in \mathrm{T} \cdot
$$

つまり, $z_{t}$ が 1 の場合にのみ, その巡回輸送ルートで輸送 が行われ，0の場合には，その巡回輸送ルートは使用されな い。

目的関数は(10)式となる。

$$
\sum_{p \in P}\left(\sum_{i \in S} \sum_{j \in C}\left(c_{i j}^{p}+d_{j}^{p}\right) \cdot x_{i j}^{p}+\sum_{j \in C} \sum_{k \in F} c_{j k}^{p} \cdot x_{j k}^{p}\right)+\sum_{t \in T} C_{t}
$$

$\rightarrow \quad \min$

この方法により，巡回輸送を含めたモデルを構筑するこ とができる。しかし，後に実験結果を示すが，整数変数を 用いるため対話的な応答性能を実現することが困難であ る。次に, 対話的な応答性能を実現するために, 整数変数 を用いないモデル化と解法を提案する。

\section{4. 混合整数計画問題のダミー荷物を用いた高速 高精度解法}

対話的応答性能を実現するため, 整数変数を用いない巡 回輸送のモデルを提案する。整数変数に代えて, 各巡回輸 送ルートの積載量の積載量下限への不足量を現寸実変数 $w_{t}$ を導入する。この実変数 $w_{t}$ を用いて巡回輸送の輸送量の条 件を(11)式で表す。

$$
t_{1} \leq \sum_{p \in P \in \sum_{i} \leq t} v^{p} \cdot y_{i t t}^{p t}+w_{t} \leq t_{2} \quad \forall t \in \mathrm{T} \cdot \cdots
$$

つまり，巡回輸送ルートの車両の荷物量が下限に満たな い場合には，ダミーの荷物を $w_{t}$ だけ車両に積載し，その輸
送コストを目的関数に加える。このダミーの荷量に対する 輸送コストは通常の荷物に対する輸送コストよりも大きな 值を設定する。

このモデルをまとめると以下の通りである。ここで， $\alpha$ はダミーの荷物輸送に対するコストであり, $c_{i j}^{p}$ より充分に 大きな値とする。

このとき, 目的関数は(12)式で表される。

Objective:

$$
\begin{aligned}
& \sum_{p \in P}\left(\sum_{i \in S} \sum_{j \in C}\left(c_{i j}^{p}+d_{j}^{p}\right) \cdot x_{i j}^{p}+\sum_{j \in C} \sum_{k \in F} c_{j k}^{p} \cdot x_{j k}^{p}\right) \\
& +\sum_{t \in T} C_{t}+\sum_{t \in T} \alpha \cdot w_{t} \\
& \rightarrow \min
\end{aligned}
$$

また，0-1 変数を用いた制約式(9)の代わりに次の（13)式 を用いる。

$$
t_{1} \leq \sum_{p \in P} \sum_{i \in S t} v^{p} \cdot y_{i f t}^{p t}+w_{t} \leq t_{2} \quad \forall i \in \mathrm{T} \cdots
$$

このモデルを用いて, 以下の処理により巡回輸送を含め た共同物流網の評価を行う。

（1）上記のモデルを解き, 輸送荷量が基準積載量に満た ない巡回輸送ルートを求める。

（2）（1）で求めた，巡回輸送ルートを巡回輸送ルートの 集合 Tから削除する。

（3）新しく算出した $\mathrm{T}$ を用いて, 再度, 上記のモデルを 解き，巡回輸送を含めた輸送コストを求める。

\section{5. 実験と評価}

まず，提案解法と混合整数計画法を用いるによるモデル で同一の物流構造を算出できるか検証するために, 四つの サプライヤと二つのデポ, 二つの工場, 五つの巡回輸送ル 一トからなり, 1 種類の部品を輸送する図 3 に示寸物流網で 比較評価を行った。この輸送網は, 混合整数計画によるモ デルでは, 実変数 23 , 整数変数 5 , 制約式は 23 であり, ダ ミ一荷物を用いた提案解法では, 実変数は 28 , 制約式は 23 である。

混合整数計画によるモデルを解くと四つの巡回輸送ルー トの中の 1 ルートだけ利用され残り 4 ルートは閉鎖される。 提案解法では, ダミ一荷物に該当する五つの実変数の中で 1 変数だけが 0 となり, 残りの 4 変数の值は正となった。こ の 4 変数に対応する巡回ルートでの輸送量上限に 0 を設定 して, この 4 ルートを閉鎖して再度計算を行った。この結 果は混合整数計画での解と同一であった。

次に, 80 サプライヤと 4 つのデポと 3 工場からなる共同 物流網の構築に, 提案手法を適用した。荷物種別は 20 種類 設定し, 巡回輸送ルートは, 200 ルート設定している。計算 には, Pentium4 $(2 \mathrm{GHz})$ のプロセッサと $1 \mathrm{~GB}$ のメモリを実 装した PCを用いた。

実験では, 以下の三つの解法の応答性能とコストの精度 を評価した。

（1）デポ経由近似法（Depot approximation method） 
Logistics network

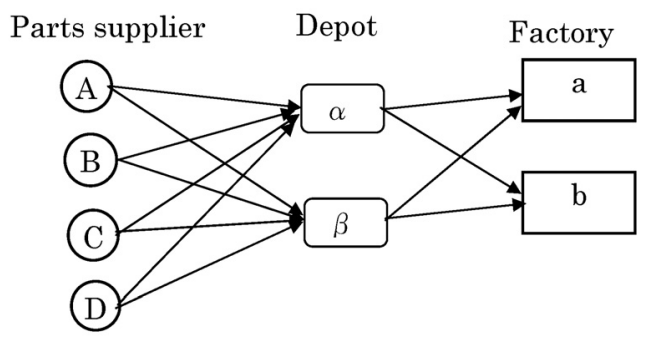

Round transportation routes

$\mathrm{A} \rightarrow \mathrm{B} \rightarrow \mathrm{a}$
$\mathrm{A} \rightarrow \mathrm{B} \rightarrow \mathrm{b}$
$\mathrm{B} \rightarrow \mathrm{C} \rightarrow \mathrm{D} \rightarrow \mathrm{a}$
$\mathrm{B} \rightarrow \mathrm{C} \rightarrow \mathrm{b}$
$\mathrm{C} \rightarrow \mathrm{D} \rightarrow \mathrm{a}$

図 3 物流網と巡回輸送ルート

Fig. 3. Logistics network and round transportation route.

実際には巡回輸送される荷物も, 全てデボ経由で輸送さ れるとして作成した最小費用流問題によるモデル化であ る。

（2）整数変数法（Integer variable method）

これは，〈3・2〉章で説明したモデル化である。

(3) 提案解法

4 章で提案したモデル化である。

〈5-1〉 応答性能評価対象の物流網を各方式でモデ ル化した場合に, 各モデルに含まれる実変数, 整数変数 $(0-1$ 変数)と制約式の数と, それぞれのモデルの求解に要する時 間を表 1 に示す。

デポ経由近似法の場合には, 1 分以内に解が求まってい る。これに対して, 整数変数法では応答時間は 1 時間を超 えているが, 提案解法では解法内部での繰り返し処理を含 めて 3 分に収まっている。

〈5·2〉 コストの評価各方式で求めたコストの評価 值を表 2 に示す。整数変数法と提案解法は, 先の図 3 の場 合と同じく，両者は同一の物流構造を算出している。これ に対して, デポ経由近似法では, 他の手法で求めた解に比 較して 10\%以上高いコストを算出している。

この誤差は, 巡回輸送とデポ経由輸送のコスト差のため である。巡回輸送はデポ集荷に比べて, 大型車両を用いる ため, 各車両の積載量が充分に確保できる場合には, 単位 荷量当りの輸送コストは低い。また，デポの利用コストも 生じない。対象とする物流網では全体の荷量の約 $30 \%$ 荙 回輸送で運ばれているため, 大きな誤差が生じている。

人間の専門家が，この物流構造（解）の見直しをした結 果, コストの評価值は 14,396 と整数変数法や提案解法に比 較して，更に $3 \%$ 近く低減した。専門家は，あらかじめ設定 されていた部品サプライヤの時間枠制約と, 車両の走行距 離の制約条件を部分的に緩和した。これにより巡回輸送を 行う車両が 1 日により多くの部品サプライヤを巡回できる
表 1 モデル規模と応答時間

Table 1. Model size and response-time.

\begin{tabular}{|c|l|c|c|c|c|}
\hline$\#$ & \multicolumn{1}{|c|}{ Method } & $\begin{array}{l}\text { Real } \\
\text { var. }\end{array}$ & $\begin{array}{l}\text { Int. } \\
\text { var. }\end{array}$ & Constraint & $\begin{array}{l}\text { Response } \\
\text { time(min.) }\end{array}$ \\
\hline 1 & $\begin{array}{l}\text { Depot } \\
\text { approximation }\end{array}$ & 6,640 & 0 & 4,892 & 0.8 \\
\hline 2 & Integer variable & 18,640 & 200 & 9,272 & 83 \\
\hline 3 & $\begin{array}{l}\text { Proposed } \\
\text { method }\end{array}$ & 18,840 & 0 & 9,272 & 2.4 \\
\hline
\end{tabular}

表 2 各解法の精度

Table 2. Accuracy of each method.

\begin{tabular}{|c|l|c|c|}
\hline$\#$ & \multicolumn{1}{|c|}{ Method } & Cost & Error(\%) \\
\hline 1 & Depot approximation & 16,801 & 11.3 \\
\hline 2 & Integer variable & 14,784 & 0 \\
\hline 3 & Proposed method & 14,784 & 0 \\
\hline
\end{tabular}

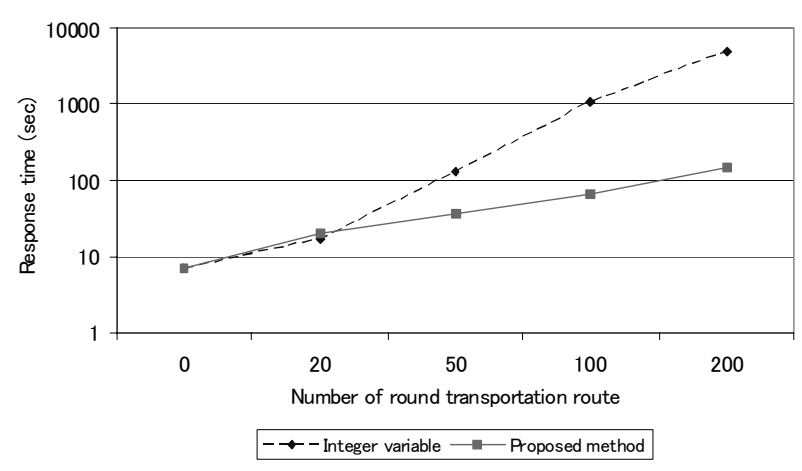

図 4 巡回輸送ルート数と応答時間

Fig. 4. Number of round transportation routes and response-time.

ようになり, デポ経由の輸送の一部が巡回輸送で代替され, コストが低減している。具体的には，専門家は 10 のサプラ イヤの出荷時間枠の拡大と, 11 台の巡回輸送車両の走行距 離の制約を緩和が可能であると判断して, この 11 台の車両 のルートに，それぞれ巡回先の部品サプライヤを一つずつ 追加する巡回輸送ルートの見直しを行っている。

〈5·3〉問題規模と応答性能更に, 提案解法の有効 性を評価するために，巡回輸送ルートが無い場合から 200 ルート設定されている場合までの応答性能を提案解法と整 数変数法で比較評価した。この評価結果を図 4 に示す。巡 回輸送ルートの数が 20 より少ない場合には提案解法より も, 混合整数計画を用いた整数変数法の応答時間は短い。

これは, この規模の問題では整数変数法でも 10 秒程度の 応答速度のため, 評価を 2 回繰り返す提案解法より応答時 間が短くなっている。しかし，巡回輸送ルート数が 100 の 場合には提案解法の応答時間は 1 分以内であるが, 整数計 画法では応答時間は 15 分を超えている。更に, 巡回輸送ル 一ト数が多くなると，この差は更に拡大している。整数変 数法では, 目標とする対話的な応答性能を実現できるのは, 巡回輸送ルート数 50 程度までに限られている。これに対し て提案解法では, ルート数が 200 の場合でも対話処理に耐 える応答性能を実現している。 


\section{6. 結 論}

本研究では，人間による多面的な評価が要求される共同 物流網の構築で, 対話処理を実現できる解法を提案した。 巡回輸送とデポ経由の輸送が混在する物流モデルを混合整 数計画問題としてモデル化した。更に，巡回輸送の車両の 積載量下限制約の判定にダミー荷物を用いることで，整数 変数を用いないモデル化と解法を提案した。ダミー荷物が 積載された巡回輸送ルートを, 輸送ルートから削除して, 次に, 再度評価することで高精度かつ高速な解法を実現し た。

提案解法を実験により評価した結果，実用規模の問題に 対しても 1 時間に $2 ， 3$ 回の対話処理を実現できている。ま た，コストの評価も人間の専門家と，ほぼ同等の精度を得 ている。

(平成 18 年 3 月 24 日受付, 平成 18 年 8 月 29 日再受付)

\section{文献}

（1）苦瀬博仁:「物流と社会問題」, 計測と制御, Vol.37, No.3, pp.166-169 (1998-3)

（2）久保幹雄：「ロジスティクス工学」, 朝倉書店, 東京 (2001)

(3) C. J. Vidal and M. Goetshcalckx : "A Global Supply Chain with Transfer Pricing and Transportation Cost Allocation", European Journal of Operational Research, Vol.129, No.1, pp.134-158 (2001-2)

(4) T. Onoyama, S. Kubota, K. Oyanagi, and S. Tsuruta : "A Method for Solving Nested Combinatorial Optimization Problems - A Case of Optimizing a Large-scale Distribution Network -, Proc. IEEE Conf. on Systems", Man, and Cybernetics 2000, pp.2467-2472, Nashville, U.S. (2000-10)

(5) G. A. P. Kindervater and M. W. P. Savelsvergh : "Vehicle routing: handling edge exchange", Local Search in Combinatorial Optimization, chapter 10, Princeton University Press, Princeton (1997)

(6) B. L. Golden, E. A. Wasil, J. P. Kelly, and I. Chao : "The Impact of Metaheuristics on Solving the Vehicle Routing Problem: Algorithms, Problem Sets, and Computational Result, in Fleet Management and Logistics, chapter 2, Kluwer Academic Publishers, Boston (1998)

(7) T. Onoyama, T. Maekawa, S. Kubota, Y. Taniguchi, and S. Tsuruta : "Constraint pre-checking and Gene build-in delaying GA for Optimizing Large-scale Distribution Networks", Proc. IEEE Conf. on Systems, Man, and Cybernetics 2003, pp.796-801, Washington D.C., U.S. (2003-10)

（8）毛利裕昭・久保幹雄・森 雅夫：「幹線配送計画問題」, 日本 $\mathrm{OR}$ 学 会 1995 年秋季研究会予稿集, pp.128-129, 東京 $(1995-9)$

（9）佐藤芳光・船越 亘・宮崎知明：「大規模部品調達ルート最適化問題 へのハイブリッド解法の導入事例」, 日本 OR 学会 2004 年春季研究 会予稿集, pp.344-345, 東京 (2004-3)

(10) J. Renaud, G. Laporte, Fayez, and F. Boctor : "A Tabu Search Heuristic for the Multi-Depot Vehicle Routing Problem", Computers \& Operations Research ,Vol.23, No.3, pp.229-235 (1996-3)

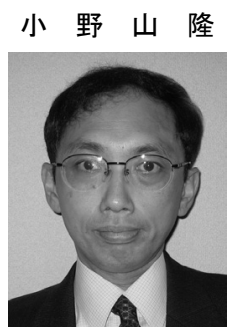

（正員） 1959 年生。 81 年 3 月大阪大学理学 部数学科卒業。同年日立ソフトウェアエンジニ アリング (株) 入社。同社技術開発本部研究部 に勤務。物流システム等の研究に従事。情報処 理学会・IEEE 各会員。

久保田仙

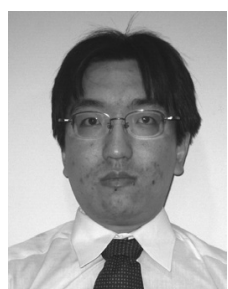

前川拓 也

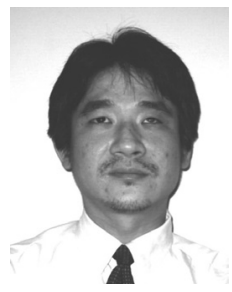

薦 田憲 久

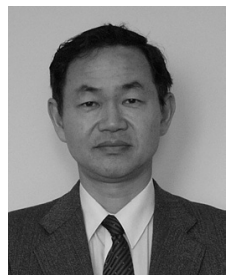

を受賞。IEEE などの会員。
(非会員) 1975 年生。9 9 年 3 月東京大学工学 部電気電子情報工学科卒業。同年日立ソフトウ エアエンジニアリング (株) 入社。同社技術開 発本部研究部に勤務。画像処理, 物流システム 等の研究に従事。情報処理学会会員。

（非会員） 1971 年生。93 年 3 月山形大学理学 部数学科卒業。同年日立ソフトウェアエンジニ アリング (株) 入社。同社技術開発本部研究部 に勤務。物流システム等の研究に従事。情報処 理学会会員。 